\title{
Interferon Regulatory Factor 4
}

National Cancer Institute

\section{Source}

National Cancer Institute. Interferon Regulatory Factor 4. NCI Thesaurus. Code C17926.

Interferon regulatory factor 4 ( $451 \mathrm{aa}, \sim 52 \mathrm{kDa}$ ) is encoded by the human IRF4 gene.

This protein is involved in the mediation of both $\mathrm{T}$-cell activation and interferon-

stimulated response element promoter-dependent gene expression. 